\title{
Mountain climbing of the grown-up patient with non-corrected congenital heart defect
}

\author{
Ireneusz Haponiuk ${ }^{1,3}$, Katarzyna Gierat-Haponiuk ${ }^{2}$, Dominika Szalewska², Piotr Niedoszytko², \\ Stanisław Bakuła ${ }^{2}$, Maciej Chojnicki ${ }^{1}$ \\ ${ }^{1}$ Department of Pediatric Cardiac Surgery, Mikolaj Kopernik Hospital, Gdansk, Poland \\ 2Department of Rehabilitation, Medical University of Gdansk, Poland \\ ${ }^{3}$ Department of Physiotherapy, Faculty of Rehabilitation and Kinesiology, Gdańsk University of Physical Education and Sport, \\ Poland
}

Kardiochirurgia i Torakochirurgia Polska 2016; 13 (1): 68-71

\begin{abstract}
Congenital heart defects (CHD) are the cause of reduced physical performance. The presence of congenital abnormalities in the heart of grown-up patients contributes to excessive hypokinesia. We present endurance parameters and a personalized comprehensive cardiac rehabilitation program before an extreme mountain climbing of a 27-year-old patient with an uncorrected ventricular septal defect (VSD). A 26-year-old female patient with an uncorrected congenital VSD was admitted to the department of cardiac rehabilitation before the planned high-mountain expedition. Professional preparation and assessment of actual exercise capacity was performed before scheduled extreme climbing. We conclude that physical activity associated with a heavy load in people with uncorrected CHD who have not developed pulmonary hypertension and reverse right-to-left flow seems to be safe, while participation of grown-up patients with congenital heart disease (GUCH) in extreme mountain climbing requires special preparation, individually designed endurance training and education program, conducted by the team of professionals in specialist centers. Key words: congenital heart defects (CHD), grown-up patients with congenital heart disease (GUCH), physical activity, endurance training, GUCH comprehensive cardiac rehabilitation (CCR-GUCH).
\end{abstract}

\section{Introduction}

Congenital heart defects (CHD), especially with left-toright shunts, are the cause of reduced physical performance. The presence of congenital abnormalities in the heart of grown-up patients, as well as structural changes due to the surgical treatment in the childhood contributes to excessive hypokinesia. In most cases the reason of low exercise tolerance is not an active disease itself but the fear of

\section{Streszczenie}

Wrodzone wady serca powodują zmniejszenie wydolności fizycznej. Obecność wrodzonych anomalii w sercu dorosłego pacjenta przyczynia się do nadmiernej hipokinezji. W pracy przedstawiono parametry wytrzymałościowe 27-letniej pacjentki z nieskorygowanym ubytkiem przegrody międzykomorowej i omówiono spersonalizowany i wszechstronny program rehabilitacji sercowej, który pacjentka przeszła przed planowanym uprawianiem wspinaczki ekstremalnej. Pacjentka w wieku 26 lat została przyjęta na oddział rehabilitacji kardiologicznej z nieskorygowanym ubytkiem przegrody międzykomorowej przed planowaną wyprawą wysokogórską. Przed ekspedycją przeprowadzono profesjonalny program przygotowawczy oraz dokonano oceny faktycznej wydolności fizycznej. W podsumowaniu stwierdzono, że aktywność fizyczna związana z dużymi obciążeniami u osoby z nieskorygowaną wrodzoną wadą serca, u której nie doszło do rozwoju nadciśnienia płucnego i odwróconego prawo-lewego przepływu, wydaje się bezpieczna, niemniej jednak uprawianie ekstremalnej wspinaczki górskiej przez dorosłych pacjentów z wrodzonymi wadami serca wymaga specjalnych przygotowań obejmujących spersonalizowane treningi wytrzymałościowe i programy edukacyjne pod nadzorem profesjonalistów w specjalistycznych ośrodkach.

Słowa kluczowe: wrodzone wady serca, wszechstronna rehabilitacja kardiologiczna.

health worsening due to excessive training. There is still no clear answer to the major, while repeatedly asked question, whether CHD is a definitive contraindication to competitive sports, especially extreme sports. General guidelines for physical activity in the grown-up patients with CHD (grownup patients with congenital heart disease - GUCH) recommend an individual approach to participation in sports. A suitable strategy of intensity of trainings and preparation

Address for correspondence: Dr. Ireneusz Haponiuk, Pediatric Cardiac Surgery, Mikolaj Kopernik Hospital, 1-6 Nowe Ogrody St., 80-803 Gdansk, Poland, phone: +48 506111 870, e-mail: ireneusz_haponiuk@poczta.onet.pl 
for more excessive challenges should be chosen on a caseby-case basis. The form of an individualized comprehensive cardiac rehabilitation program (CCR-GUCH) is preferred [1].

Mountain climbing is associated with physical efforts in terms of rapid atmospheric pressure changes, low oxygen concentration in the air, and permanently reduced ambient temperature. Therefore, high mountain activities result in a heavy cardiovascular load as well. In high altitudes symptoms of acute mountain sickness (AMS) can appear despite certain preparing, and they include headache, sleep disturbances, loss of appetite, peripheral edema (usually face edema, mainly the eyelids), strong palpitations, nausea and/or vomiting, and dyspnea after a relatively little effort [2]

The purpose of the study was to present endurance parameters and a personalized comprehensive cardiac rehabilitation program before extreme mountain climbing of a 27-year-old patient with an uncorrected ventricular septal defect (VSD).

\section{Clinical vignette}

A 26-year-old female patient with an uncorrected congenital perimembranous ventricular septal defect (VSD), a member of a professional mountaineering alpine club, was admitted to the department of cardiac rehabilitation before the planned high-mountain expedition. Her past sporting achievements were limited to successful climbing up to the level of $2500 \mathrm{~m}$ above sea level. Professional preparation and assessment of actual exercise capacity was recommended by the cardiologist, who was afraid of the limitations arising from CHD before scheduled extreme climbing Mont Blanc (4000 $\mathrm{m}$ above sea level) for the first time in her sport career.

The heart defect was diagnosed after birth, the patient was regularly controlled in the outpatient clinic for pediatric and congenital heart defects. Her early childhood growth was uncomplicated. The heart defect was regarded as borderline with a small left-to-right shunt (Qp : Qs-ratio below $1.5: 1$ ), with no signs of pulmonary overflow or pulmonary hypertension. The girl was not referred for surgical treatment due to a stable clinical course and mild hemodynamic consequences, with good physical capacity. Her life-passion was mountain climbing, and there were no established medical limitations for mountaineering up to the altitude of $2000 \mathrm{~m}$.

Current echocardiographic examination showed a normal ventricular size and systolic function, regular anatomy and the function of the valves, with a restrictive left-toright shunt via the small (4 $\mathrm{mm})$ perimembranous VSD. Doppler examination revealed a high interventricular gradient (93 $\mathrm{mmHg}$ ) and no features of pulmonary hypertension. Atrial septum was intact, systemic and pulmonary venous returns were normal.

Electrocardiography (ECG) recorded a regular sinus rhythm 98 beats/min, clockwise rotation and incomplete right axis deviation. Laboratory blood tests remained entirely normal.

Before to the exercise capacity assessment and the beginning of individualized endurance training, the patient was presented to the consultant cardiothoracic surgeon.
After meticulous analysis of her current clinical status and echocardiographic data, the history of the disease and finally the lack of free consent to any operation declared by the patient, she was disqualified from surgery or percutaneous intervention. In view of the strong plans of highmountain climbing with a summer Mont Blanc expedition, the patient was admitted for a three-week's long personalized comprehensive CCR-GUCH program.

Her training heart rate zone was kept in the range 130-146 beats per minute. CCR-GUCH was based on an endurance cardiac program, with activation of respiratory muscles and elements of strength training. An important education how to behave in extreme physical loads with self-monitoring techniques, and learning of effective breathing with a heart rate control were conducted.

In order to fully assess the cardiopulmonary reserve and exercise capacity before and after the climbing, cardiac imaging was supplemented by a functional assessment, including cardiopulmonary exercise testing (CPX). The initial CPX was performed immediately before commencing the alpine expedition. We used a classic bicycle ergometer following the ramp protocol with an initial load of $5 \mathrm{~W}$ and the increase of load at $10 \mathrm{~W} / 1 \mathrm{~min}$. This test was terminated with a load of $129 \mathrm{~W}$, peak oxygen uptake $\left(\mathrm{VO}_{2}\right.$ peak $)$ $26 \mathrm{ml} / \mathrm{kg} / \mathrm{min}, \mathrm{HR}$ 172/min, peak respiratory exchange ratio (RER peak) 1.13, $\mathrm{VO}_{2}$ (AT) $18 \mathrm{ml} / \mathrm{kg} / \mathrm{min}, \mathrm{VE}\left(\mathrm{VCO}_{2}\right)$ slope 27. The second CPX was conducted after her returning from the expedition. Both tests were terminated due to maximal fatigue of the patient (18 points of Borg scale). No ischemic changes, arrhythmias or conduction abnormalities were observed in the ECG. The anthropometric parameters and results of both exercise tests are shown in Table I.

Tab. I. Parameters obtained during the stress test before departing and after returning from the expedition

\begin{tabular}{|c|c|c|}
\hline Parameter & $\begin{array}{l}\text { CPX } 1 \text { (before } \\
\text { the expedition) }\end{array}$ & $\begin{array}{l}\text { CPX } 2 \text { (directly after } \\
\text { the expedition) }\end{array}$ \\
\hline Height [m] & 1.64 & 1.64 \\
\hline Weight [kg] & 56 & 56 \\
\hline BMI $\left[\mathrm{kg} / \mathrm{m}^{2}\right]$ & 21 & 21 \\
\hline Peak $\mathrm{VO}_{2}[\mathrm{ml} / \mathrm{kg} / \mathrm{min}]$ & 26 & 28 \\
\hline $\mathrm{VO}_{2} \mathrm{AT}[\mathrm{ml} / \mathrm{kg} / \mathrm{min}]$ & 18 & 17 \\
\hline VE/VCO ${ }_{2}$ slope & 28.1 & 28.3 \\
\hline WR [Watt] & 129 & 132 \\
\hline$H R_{\max }[1 / \min ]$ & 172 & 165 \\
\hline $\mathrm{HR}$ at rest [1/min] & 89 & 73 \\
\hline $\mathrm{BF}$ at rest $[1 / \mathrm{min}]$ & 25 & 21 \\
\hline $\mathrm{BF}_{\max }[1 / \min ]$ & 33 & 30 \\
\hline VE at rest [l/min] & 14 & 10 \\
\hline $\mathrm{VE}_{\max }[\mathrm{l} / \mathrm{min}]$ & 51 & 47 \\
\hline
\end{tabular}

CPX 1 - initial cardiopulmonary exercise test before the expedition, CPX 2 cardiopulmonary exercise test after the expedition, $\mathrm{BMI}$ - body mass index peakVO $\mathrm{V}_{2}$ - peak oxygen consumption, $\mathrm{VO}_{2} \mathrm{AT}$ - oxygen consumption at the anaerobic threshold, VE/ $\mathrm{VCO}_{2}$ slope - ventilation as a function of respiratory carbon dioxide equivalent, $\mathrm{WR}$ - work load, $\mathrm{HR}_{\text {max }}$ - maximal heart rate, $\mathrm{HR}$ at rest - heart rate at the rest, $B F$ - breathing frequency, $V E$ at rest - lung ventilation at rest, $\mathrm{VE}_{\max }$ - lung ventilation at peak of exercise 
While climbing the Mont Blanc (4810 m above sea level) the patient was asked to check and register her pulse regularly, and to observe accompanying clinical symptoms. Those recordings were conducted in each intermediate station in the mountains. While climbing the following values of heart rates were obtained: station Nidd Aigle $2372 \mathrm{~m}$ above sea level: HR 68/min; station Refuge des Houches Rognesles 2768 m above sea level: HR 108/min; station Aig du Gouter 3817 m above sea level: HR 116/min. After entering the station Vallot $4363 \mathrm{~m}$ above sea level at air temperature of minus $8^{\circ} \mathrm{C}$ : HR $116 / \mathrm{min}$.

The first symptoms of AMS in the form of worse-being and perceived needs of longer rest already appeared above the height of $3000 \mathrm{~m}$ above sea level. Due to the severity of the symptoms of AMS in the form of persistent headaches, shortness of breath, dry cough and general weakness, the patient decided to stop climbing after 14 days of the expedition, reaching a height of $4400 \mathrm{~m}$ above sea level [2].

\section{Discussion}

The problems of adolescent patients with congenital heart diseases (GUCH) are becoming more noticeable due to the increasing number of such cases in the population [2]. In this group there are also patients awaiting an unlimited participation in life activities, including extreme sports. Proper selection of forms of activity and exercise preparation for extreme sports is an important issue, which may anticipate not only successes in competitions, but first of all, the safety of the constraints imposed by congenital heart disease [3].

Exercise capacity of patients with CHD in the Polish population, with those after correction of the most typical cardiac septal defects, is reduced, and worse when compared to healthy population [3-5]. An effective way to improve exercise tolerance is participation in comprehensive cardiac rehabilitation programs dedicated to $\mathrm{GUCH}$ patients [6-8]. Following literature data and institutional experience, authors undertook a task of preparation of an adolescent patient with uncorrected VSD for high mountain climbing. This extreme sport naturally appeared to be reserved for a highly selected group of completely healthy enthusiasts, in whom any deterioration of health preclude further climbing. The issue of a potentially negative impact of competitive sports on a completely healthy heart cannot be ignored either [9]. The exposure of patients with CHD to changes in atmospheric pressure at high altitude was the subject of detailed studies in patients flying in planes [10]. The final arguments for controversial qualification of women for CCR-GUCH before extreme climbing were excluded pulmonary hypertension and reverse rightto-left shunts.

For the preparation for the expenditure, a monitored program of comprehensive cardiac rehabilitation was used. The preparation process was carried out for a month, including initial interval endurance exercise training, with a continuous increase until the work load of 100 Watts. Learning of effective breathing was very valuable in the patient's treatment. Despite the natural value of breathing control in extreme circumstances, it helped to gain the ability to acquire the respiratory compensation in rarefied mountain air. Following the effective breathing instructions at the time of climbing she was able to increase the volume of breath and reduce the energy associated with frequent shallow breaths. We want to emphasize that in her opinion these practical skills were very helpful to facilitate extreme effort in high altitudes, against the threat of AMS [2]. This is confirmed by the observed slight decrease in ventilation at rest and during maximum exercise efforts, accompanied by a subjective sense to improve heart performance in subsequent CPX studies.

The program was carried out using standard equipment used for CCR $[8,11,12]$. The process of preparation of the individual with an uncorrected CHD following general principles of endurance training appears to be an original solution of a rare problem, although we cannot exclude the use of our experience also in other GUCH patients declaring their intention to participate in extreme sports.

Directly after the completion of individualized CCRGUCH training, the patient underwent a CPX to check and prove the ability to undertake difficulties of the expedition. The next evaluation was made shortly after her return from the Alpine expedition. Both tests were performed on the same bicycle ergometer according to a ramp protocol with the initial load of $5 \mathrm{~W}$ and a constant $10 \mathrm{Watt} / \mathrm{min}$ load increment. The anaerobic threshold was determined by the V-slope method and verified by respiratory equivalents, according to generally accepted principles for the assessment of patients with cardiovascular problems [11, 13].

During subsequent exercise tests (before and after climbing), no significant endurance parameter changes were observed, while there was a significant decrease in resting and maximum HR. These changes are typical of patients undergoing regular endurance training $[9,14]$.

In our opinion, participation in extreme mountaineering of the patient with an uncorrected CHD must not be considered in terms of competition, it is just a personal success by itself. Meticulous medical examination and specialized preparation allowed for safe overcome of hardships of the Mont Blanc expedition. The ability to have self-conscious control of the cardiovascular and pulmonary indicators like $\mathrm{HR}, \mathrm{BP}$ and breathing parameters, proved to be decisive for the safety of our patient.

Regardless of comprehensive preparation, the symptoms of foreseeable AMS appeared, while were properly identified by the woman. The intense course of AMS could be caused by insufficiently short acclimatization time at each altitude (rest periods), adapted to healthy members of the expedition [15].

Since research on small groups and descriptions of clinical cases are treated in accordance with the principles of EBM as not very strong evidence, it is desirable to extend the research on the impact of CCR and high mountain expeditions on population of young adults with hemodynamically insignificant CHD. 


\section{Conclusions}

1. Physical activity associated with a heavy load in people with an uncorrected CHD who have not developed pulmonary hypertension and reverse right-to-left flow seems to be safe.

2. Participation of GUCH patients in extreme mountain climbing requires special preparation, individually designed endurance training and education program, conducted by the team of professionals in specialist centers.

\section{Disclosure}

Authors report no conflict of interest.

\section{References}

1. Kompleksowa rehabilitacja kardiologiczna. Stanowisko Komisji ds. Opracowania standardów Rehabilitacji Kardiologicznej Polskiego Towarzystwa Kardiologicznego. Materiały zalecane przez sekcję Rehabilitacji Kardiologicznej i Fizjologii Wysiłku Polskiego Towarzystwa Kardiologicznego. Folia Cardiologica 2004; 11 (supl. A).

2. Fiore DC, Hall S, Shoja P. Altitude illness: risk factors, prevention, presentation, and treatment. Am Fam Physician 2010; 82: 1103-1110.

3. Kawalec W, Turska-Kmieć A, Żuk M, Błaż W, Kowalczyk M, Ziółkowska L, Jagiełłowicz D, Maryniak A. Poprawa opieki kardiologicznej nad dzieckiem z patologią układu krążenia ze szczególnym uwzględnieniem oceny wyników leczenia i lepszej jakości życia dzieci z wrodzonymi wadami serca. Ogólnopolski program wielozadaniowy i wieloośrodkowy realizowany w ramach programu POLKARD 2006-2008. Standardy Medyczne/Pediatria 2009; 6: 614-622.

4. $36^{\text {th }}$ Bethesda Conference. Recommendations for determining eligibility for competition in athletes with cardiovascular abnormalities. J Am Coll Cardiol 2005; 45: 1318-1375.
5. Gierat-Haponiuk K, Haponiuk I, Chojnicki M, Kwiatkowska J, Zielińska D, Bakuła S. Ocena wydolności fizycznej i stanu psychicznego pacjentów w odległym okresie po kardiochirurgicznej korekcji wrodzonych wad serca. Kardiochir Torakochir Pol 2009; 6: 293-299.

6. Gierat-Haponiuk K, Haponiuk I, Chojnicki M, Jaworski R, Bakuła S. Wydolność fizyczna i jakość życia pacjentów w odległym okresie po kardiochirurgicznej korekcji wrodzonych wad serca. Kardiol Pol 2011; 69: 810-815.

7. Szydłowski L, Marek-Szydłowska T, Dumała J, Dobosiewicz K. Wydolność wysiłkowa po korekcji wad wrodzonych serca. Standardy Medyczne 2004; 11: 1186-1188.

8. Gierat-Haponiuk K, Haponiuk I, Jaworski R, Chojnicki M, Szalewska D, Leszczyńska K, Bakuła S. Physical activity in patients with grown-up congenital heart defects after comprehensive cardiac rehabilitation. Kardiochir Torakochir Pol 2014; 11: 452-458.

9. Leischik R. Endurance sport and cardiac injury. Kardiol Pol 2014; 72: 587-597.

10. Harinck E, Hutter PA, Hoorntje TM, Simons M, Benatar AA, Fischer JC, de Bruijn D, Meijboom EJ. Air travel and adults with congenital heart disease. Circulation 1996; 93: 272-276.

11. Dylewicz P, Jagier A, Piotrowicz R, et al. Kompleksowa rehabilitacja kardiologiczna. Stanowisko Komisji d.s. Opracowania Standardów Rehabilitacji Kardiologicznej PTK. Folia Kardiol 2004, 8: 20-31.

12. Wytyczne Europejskiego Towarzystwa Kardiologicznego dotyczące leczenia dorosłych pacjentów z wadami wrodzonymi serca (nowa wersja 2010). Kardiol Pol 2010; supl. IX: 639-696.

13. Trojnarska O, Straburzyńska-Migaj E, Oko-Sarnowska Z, et al. Spiroergometryczna ocena wydolności wysiłkowej u pacjentów po 30 roku życia z drożnym ubytkiem międzyprzedsionkowym. Folia Cardiol 2005; 12: 125-132.

14. Terrien J, Per Morten F, Walker M, Granton J, Reid GJ, Webb G. A pilot study of exercise training in adult patients with repaired tetralogy of Fallot. Can J Cardiol 2003; 19: 685-689.

15. Schneider M, Bernasch D, Weymann J, Holle R, Bartsch P. Acute mountain sickness: influence of susceptibility, preexposure, and ascentrate. Med Sci Sports Exerc 2002; 34: 1886-1891. 